\title{
Digital Transactional Tools and Their Optimum Use in Language Learning: An Interdisciplinary Approach
}

\author{
${ }^{1}$ Arul P Gaspar, ${ }^{2}$ Roseline Mary R \\ ${ }^{I}$ Asst. Professor, Department of English, Christ University, Bangalore \\ ${ }^{2}$ Asst. Professor, Department of Computer Science, Christ University, Bangalore
}

\begin{abstract}
Our learning culture and education system have taken a techno-craft stand and the teaching-learning process without classroom is on the move today. Learning style has been shaped ever since we encountered cyber technology and brought the same to language classrooms. Bringing technology in education, especially language learning caters to the need of contemporary language learners. Today, language learning is empowered by techno-centric, socio-economic, political, cultural and academic environments. It's not just LSRW; it is not just the basic language skills. It is the Digital tools that are becoming part and parcel of language teaching-learning process and are enhancing the learning objectives to boost one's higher order thinking. These digital tools reengineer the very purpose of language teaching and make a significant contribution in education to help teachers teach effectively. In fact, the language learners exercise their linguistic ability in an informed manner. The traditional way of teaching English has taken a back stage and technology-centred, newer methods and methodologies are stepping up in this $21^{\text {st }}$ century. This interdisciplinary study explores certain digital tools which enhance the language learners' approach to language learning and their effective implementation of technology in a language learning setup. It also throws light on a few tools such as Sephonics, Hot Potatoes, Eclipse Crossword and Interactive White Board and their functions and applications in English language learning. This analytical study is the synthesis of two disciplines-Computer Science and English Language and Literature Studies. On the one hand, this paper deals with LSRW and how these skills are developed by Digital Literacy, Digi-visual Mode of learning, Digital-audiographic Mode of teaching-learning process and Awareness of various apps and their optimal use in the language learning sessions. On the other hand, this study shows the application of this framework using a few digital tools and running them in the classroom environment for practical exposure and better understanding.
\end{abstract}

Keywords: Digital Literacy, Digi-visual Mode, Digital-audio-graphic Mode, Techno-centric, LSRW.

\section{Introduction}

Our approach to life is girded by the digital age and the techno-driven attitude in acquiring knowledge. We use varied digital tools to empower our practical learning ability. Today, the conventional teacher and the learning environment are challenged by the free, unrestricted learning environment-Digital Learning Environment. It is not just LSRW, the four skills-listening, speaking, reading and writing in a language learning classroom. These skills in a traditional way make language learners master the language but they help the learners very little using or applying it a real-world situation. Chen and Jiang (2012) in Integration of ICTs into Subject Teaching in Pre-service English Teacher Education state that teaching English does not mean providing language learners with adequate knowledge and skills, but it refers to providing them with a conducive, learning atmosphere to strengthen their interest for learning which becomes very meaningful in real life.

This interdisciplinary study does not focus on available new technologies usable in the language learning classroom and nor does it talk about inadequacies of conventional language teaching-learning process but it gives specific attention to the efficacies of the digital learning atmosphere in a language session. This approach illustrates how this atmosphere enhances the students' understanding of the target language.

UNESCO in the year 1998 released a report-Teachers and Teaching in a Challenging World and it tells about the drastic and historic change introduced with the advent of ICTs in the conventional teaching-learning process ("Information and communication technologies in teacher education ------- a Planning Guide," 2002, p.n). The contribution of Information and Communication Technologies has been very evident and the teachers are aware of the use of them in teaching-learning process. Thus ICTs have enabled the learners, the teachers, the teaching techniques and the learning strategies in such a way that the conventional teaching has given way to the integration of ICTs in English language learning. This integration has transformed the language learning style (Yan \& Yuhong, 2012, p.5). Nevertheless, this paper shows how this ICT-enabled language learning is powered further by certain digital-transactional tools such as sephonics, hot potatoes, eclipse cross word, IWB, etc. The purpose of this interdisciplinary study is to describe the framework designed to showcase this digitaltransactional mode in the language learning classroom, to illustrate the digital tools that enable this radical 
change in the language teaching-learning process and to learn the optimum use of these transactional tools in a language learning setting that is empowered by techno-centric and digital-age-empowered socio-economic, political, cultural and academic environments.

\section{Optimum Use of the Digital-transactional Tools}

The term "optimum" refers to "producing the best possible results" ("Oxford Advanced Learner's Dictionary,"2005, p.1067). The use of digital tools to teach and learn English language, especially all the four skills-LSRW must provide the teachers and the learners with the optimum time and place for meaningful language learning. And this best possible way is viable only when the teaching community understands the functions of Digital Literacy World.

The world is slowly taking a transformation to a digital environment which serves as a bridge to "a more engaged, relevant, meaningful and personalized learning-all of which can lead to a higher academic achievement" (North Central Regional Educational Laboratory and the Metiri Group [NCREL], 2003). This digital literacy will help the English language learners in higher order thinking and sound reasoning. The days are gone where technology is used in scientific areas but these digital tools also play a vital role in English language learning. It is worth asking questions such as: what do these digital tools do in the learning environment? And how do they function to make the teaching-learning process very effective in the classroom?

\section{Transactional Method in Language Learning}

The answer is transactional method in learning English language in which the digital tools function like a catalyst to make the learners get involved in listening, speaking, reading and writing skills. The term "transaction" means "the process of doing something" ("Oxford Advanced Learner's Dictionary,"2005, p.1630). In fact, the language learners want to learn the correct pronunciation, they would like to pick up active reading and comprehend the passages better, they are keen to use new vocabulary words while dialoguing with others in English, and the language learners have a strong desire to express their thoughts clearly through their writing. Here, in all these productive and receptive skills, something is happening or taking place between the language learner and the skills. This very act of exchange is process oriented. And this process of listening, speaking, reading and writing something in English occurs in mind. The language learners' faculty is fully involved in interaction which transacts the digital learning in the classroom.

Generally the Transactional theory is used or applied in the field of teaching literature studies especially with poems. Here the language learners are encouraged to explore the text, discover something in their reading and discuss with their peers and this becomes more meaningful in a reciprocal response. So this Transactional theory refers to "reciprocal, mutually defining relationship" (Rosenblatt, 1986) between the language learner-reader and the reading material-the poem. In the same way, when the learners use the digital tools to learn English, they explore each tool offered to them, they understand the functions, they also feed on the tools with their learning in the form of questions, answers, writings, etc. This learning becomes purely reciprocal and mutually transacted something to better the learning. This very exchange or transaction between a digital tool and a language learner can be well illustrated by Annie Dillard's metaphor. Dillard states that "The mind fits the world and shapes it as a river fits and shapes its own banks" (1982). Through this statement, she illustrates the reciprocal relationship between the river and its banks. They both become complimentary to each other in contributing something expected out of a serious process. It is also the same with the digital tools used in the language classroom and the digital transaction taking place between the learners and the tools. And the result is their effective learning of any skills in real life.

\section{Factors that Influence the effective language Learning}

The transaction can be best comprehended through the following factors that influence the effective language learning. They are digital literacy, digi-visual mode of learning, digital-audio graphic mode, the learners' awareness of various apps for language learning. These factors individually become responsible to help the learners get along with the digital tools such as Interactive white Board, Hot Potatoes, Sephonics and Eclipse Crossword. The digi-visual mode of learning enhances the learners' sense of imagination. They free play their imagination, form a mental picture, and try to understand the concept through the pictures. To strengthen their learning, the visual pictures, diagrams, colourful, pie-charts, etc make them form a clear understanding and interpret them well in writing. Now these digital tools provide the learners with 3-D animated objects which can be described, characterised, and illustrated in a lucid manner. The digital-audio graphic mode of learning deals with the tools such as Sephonics, Eclipse Crossword and Interactive White Board. It is very difficult to speak English the way the native speaker might do because any bilingual may face a series of issues with pronouncing English words as they are to be pronounced. Though, the language learners acquire the knowledge of International Received Pronunciation (IRP) through study and varied exercise, they fail to produce the specific sound as it demands in real life. This situation leads to a sort of confusion in understanding the native speaker's 
or other English speaker's very idea of the dialogue. But this digital-audio graphic mode of learning solves the problem and makes the learners receive the correct sound and produce the same in return. Moreover, the learners' awareness of varied apps available in the market free of cost takes them to another level in terms of learning English language. Thus, the language skills-LSRW are best learned through this transactional method with the help of these digital-transactional tools in a language classroom. (See framework in Figure 1.) This initial research tries to show the nature and function of the tools that are of great interest in the language learning classroom.

\section{Sephonics}

Sephonics is a perfect digital-transactional tool to learn phonetics effectively. This tool guides the language learners systematically and helps them become independent in learning the sounds. The language learners may find it difficult initially but the tool is so interactive and makes them reciprocal in mastering the phonetic symbols or sounds. "This software will allow us to get familiar with the English alphabet, do tons of practice in matching sound with phonetic symbol, do spelling activities, listen to a word and identify its phonetic transcription, get familiar with reading the phonetic script and transcribe words into their phonetic script" (My That's English, 2012). When language learners get into all these transactional activities, they experience the knowledge of phonetics in real life. This learning becomes authentic in digital language learning setup. (See Sephonics tool in Figure 2.)

\section{Hot Potatoes}

Academic vocabulary is needed for the English language learners to develop their understanding, reading and writing skills. Students who lack this academic vocabulary fail to comprehend the lectures and also are hampered in their ability to express themselves in writing. Hot Potatoes is a software which has a collection of tools that are used for the purpose of self assessment with web based activities. This digital-transactional tool includes JQuiz, JCloze, JCross, JMix, JMatch exercises which help the learners improve their vocabulary building habit in English language learning (Zhe, 2012, p. 275-279).

\section{Eclipse Crossword}

Crossword puzzles generally help one's logical reasoning and thinking. This digital-graphic tool encourages the teachers and the students to review their subject related registers or terminologies and lessons for all subjects. The language learners are guided step by step with easy commands such as Create Crossword Puzzle, Open the publishing options from where you can save the files, Export the clues, Export the puzzle grid, Open the clues in word, Add the puzzle grid and Rearrange and customize (Welcome to Eclipse Crossword, 1999-2013). In fact the learners enjoy making their own word list that enriches their academic writing and communication in the long run.

\section{Interactive White Board}

This is an amazing tool that adds colours and flavours inside the classroom with more interactive and collaborative way of teaching-learning process. IWB, as a digital-transactional tool functions like a catalyst to teach all the four skills with the strong support from sensory detail chart. It also helps teachers to engage the students of different intelligences such as auditory, visual and kinaesthetic learners. Auditory learners would like to hear more and recite, whereas visual learners like to see a lot through graphs, pictures, graphics and kinaesthetic type would like to have a hands-on experience in learning English language learning (LearningRx, 2003-13). This interactive board motivates the learners in class room participation and group discussions in much more effective way. This interactive tool equips teachers to target all the students in the classroom in a more flexible way though.

\section{Conclusion}

The ultimate chase after these digital-transactional tools is to take the teaching-learning process and pedagogy to a higher level and match with the thought process of this information and digital age. Today, students are highly familiar with the latest electronic gadgets connected to cloud computing. The language learners can have all possible apps to download any material related to English language learning. The learners have the best possible access today to improve their language learning. They can exploit these digital tools maximum to their ability so that learning becomes fun and learning is done for life rather than for the sake of learning within four walls. But the challenge is the teachers' and students' aptitude and attitude for this digitaltransactional learning and how they are willing to adapt to this E-era. 


\section{References}

[1]. Chen, Y,. \& Jiang, Y. (2012). Integration of ICTs into subject teaching in pre-service English teacher education. Information Technology Based Higher Education and Training (ITHET), International Conference, 1, 5. doi: 10.1109/ITHET.2012.6246032

[2]. Dillard, A. (1982). Living by Fiction. New York: Harper \& Row.

[3]. Eclipse Crossword. (1999-2013). Welcome to Eclipse Crossword. Retrieved from eclipsecrossword website: http://eclipsecrossword.com

[4]. Hornby, A.S. (2005). Oxford Advanced Learner's Dictionary. New York: Oxford University Press.

[5]. Hornby, A.S. (2005). Oxford Advanced Learner's Dictionary. New York: Oxford University Press.

[6]. LearningRx. (2003-130). Train the brain. Get smarter. Guaranteed. Retrieved from learningrx website:http://www.learningrx.com/types-of-learning-styles-faq.htm

[7]. Literacy in the Digital Age. (2003). North Central Regional Educational Laboratory and the Metiri Group, 10. Retrieved from http://www.ncrel.org/engauge

[8]. My That's English. (2012). Sephonics, the perfect tool to learn phonetics. Retrieved from mythatsenglish website:http://mythatsenglish.blogspot.com/2012/04/sephonics-perfect-tool-to-learn.html

[9]. Rosenblatt, L.M. (1968). Literature as Exploration ( $3^{\text {rd }}$ ed.). New York: Noble and Noble.

[10]. UNESCO. (2002). Information and communication technologies in teacher education -------- a Planning Guide.

[11]. Wible, D,. Chin-haw, K., \& Nai-Lung, T. (2004). Contextualizing language learning in the digital wild: tools and a framework. Advanced Learning Technologies, Proceedings, IEEE International Conference, 231-235. doi: 10.1109/ICALT.2004.1357409

[12]. Zhe, Y. (2012). The application Research of Hot potatoes in English web Test fabrication. Lecture Notes in Information Technology, 16-17, 275-276. Retrieved from http://www.ier-institute.org/2070-1918/lnit17/v17/275.pdf

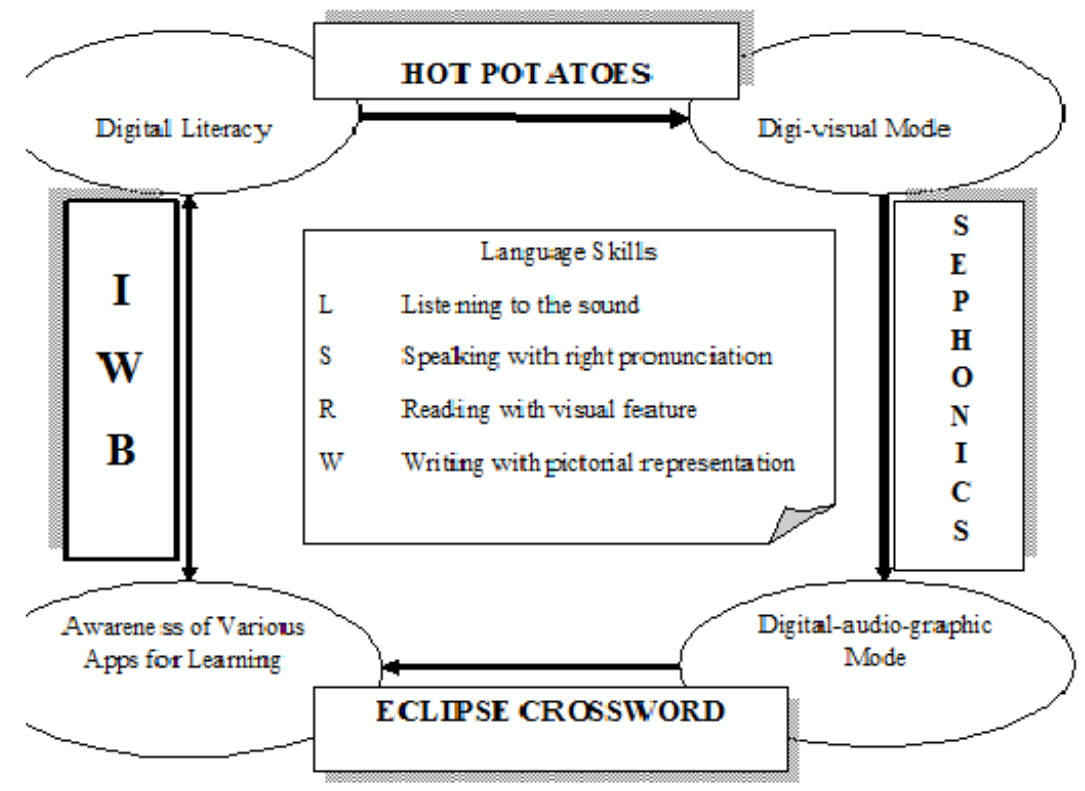

Fig 1 Factors that influence the effective language learning

Fig 1This framework titled, factors that influence the effective language learning helps us understand the specific transaction that takes place between language learners and the digital transactional tools used in the language learning classroom.

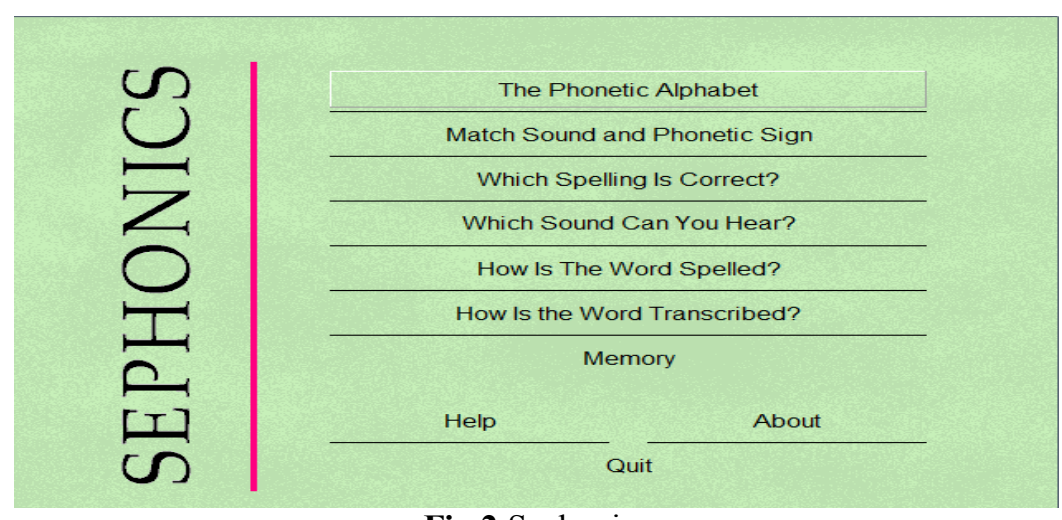

Fig 2 Sephonics

Fig 2 demonstrates the phonetic alphabet. There are also many exercises which matches the sound and phonetic sign. This tool helps the language learners how is the word spelled and transcribed. It includes different seven different exercises for practicing English. 